\title{
EFFECT OF BLOOD TRANSFUSION ON RHEUMATOID ARTHRITIS
}

\author{
BY \\ N. R. W. SIMPSON, G. D. KERSLEY and D. HALL BROOKS \\ From the Royal National Hospital for Rheumatic Diseases, Bath
}

\section{Introduction}

Blood transfusion as a method of treatment of rheumatoid arthritis has been employed by Copeman (1931a, b), Holbrook and Hill (1936), Hench (1938), Hartung (1943), Appelqvist and Holsti (1947), and others. The aim of this investigation was to find the effect of transfusions of whole blood, concentrated red cells, and plasma on the blood and general condition of patients suffering from the rheumatoid type of polyarthritis.

The patients were those normally admitted to the Royal National Hospital for Rheumatic Diseases, Bath, during 1948. No special selection was made, but most had moderately or very severe illness.

Serial plasma protein estimations, sedimentation rates, crude and corrected suspension stability (C.S.S.) readings, haematocrit readings, and haemoglobin estimations were made in all cases, and red cell counts were done when it was thought they might be useful. The tests were done in the first place before transfusion, and thereafter at weekly intervals. As far as possible experimental errors were eliminated ; for instance, one person was responsible for each estimation during the whole period and the technique was standardized. The biuret method was used for the estimation of the plasma proteins, and the suspension stability was estimated by the Spa method of Collins and others (1939).

The Bristol depot of the National Blood Transfusion Service supplied the whole blood, packed cells, and plasma used in these investigations, and accurate assessment of group $R h$ and other factors were made in every case. No severe transfusion reaction was ever noted, but a mild rigor occurred in four cases. Usually each transfusion consisted of 2 pints of packed red cells or whole blood. The majority of patients had only one transfusion, but this was repeated in some cases where it was considered necessary, and a few patients had three separate transfusions.
Controls on 25 normal people gave the following results :

Plasma Proteins :

Total Protein 5.8-8.6 g. \%.

Fibrinogen 0.1-0.4 g. \%.

Albumin $3 \cdot 0-6 \cdot 5$ g. $\%$.

Globulin $0 \cdot 9-2 \cdot 5$ g. $\%$.

A

$\overline{\mathbf{A}}$ ratio $4: 1-1 \cdot 2: 1$.

Haemoglobin $100 \%-14$ g. standard.

Haematocrit $42-45 \%$.

Sedimentation Rate (Wintrobe, crude)-

C.S.S. $85-95 \%$.

0-15 female, 0-10 male.

\section{Initial Plasma Proteins in Sixty Patients}

Complete plasma protein estimations were carried out on sixty patients with rheumatoid arthritis. The fibrinogen values were high in thirtyeight, high normal in sixteen $(0.4$ per cent.), and well within normal limits in six cases only. The globulin content was raised above $2.5 \mathrm{~g}$. in twenty-one cases, ten also having a lowered albumin value, while in thirty-nine normal values were obtained. The patients with raised globulin and lowered albumin figures had a severe form of the disease as measured by extent of involvement, pain, loss of weight, anaemia, and C.S.S., but some patients whose plasma proteins were within normal limits were also as severely affected. All patients showed secondary microcytic anaemia of varying severity, and abnormal crude and corrected erythrocyte sedimentation rate (E.S.R.).

\section{Effect of Transfusion on Fifty Cases}

Fifty cases have so far been treated by transfusion and adequately followed up biochemically and clinically. Forty were given transfusions of packed cells or whole blood, and ten have been given plasma transfusions, three of these subsequently having a 


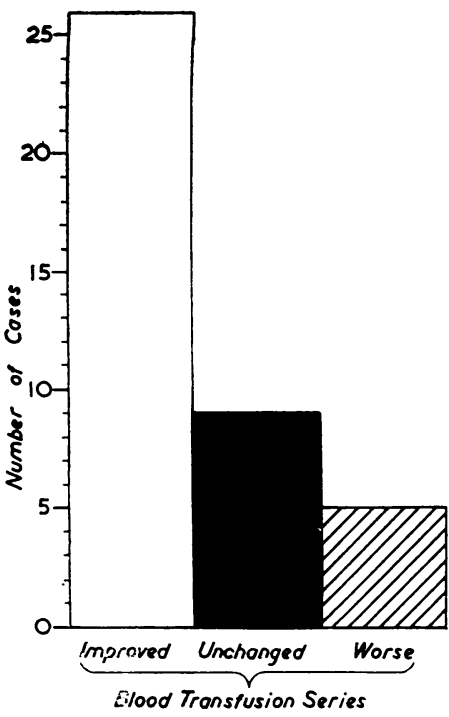

A

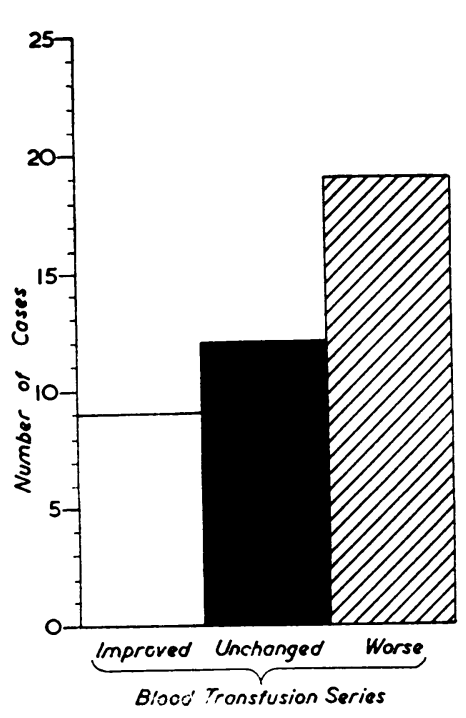

A

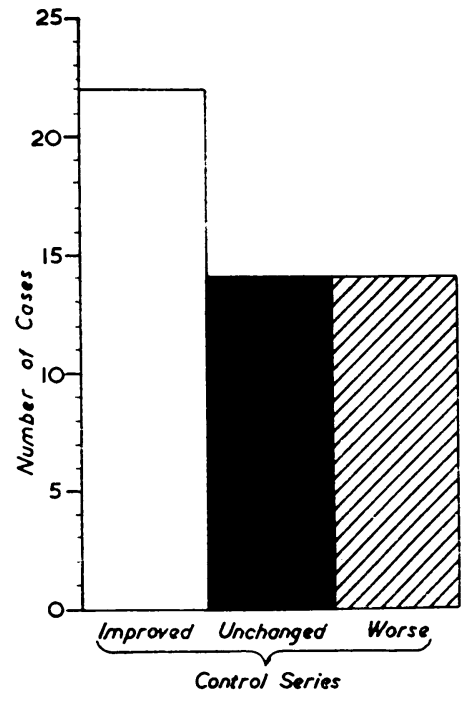

B

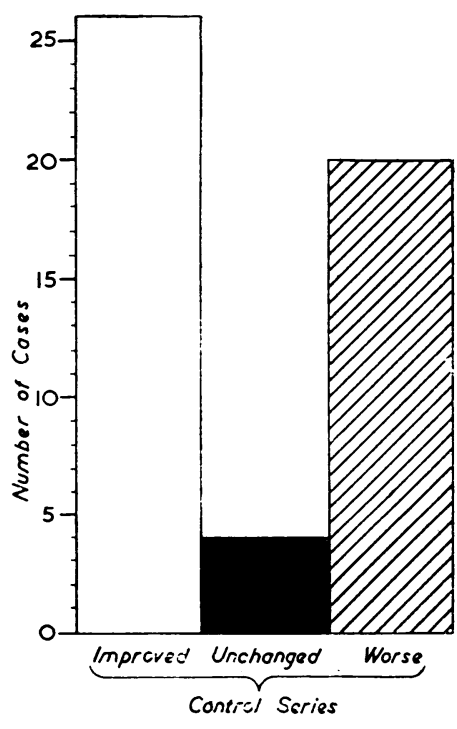

B
FIG, 1-Crude sedimentation $\mathbb{D}$ rate. Blood transfusion series forty cases ; controls fifty cases. All were followed up for six $\vec{O}$ months.

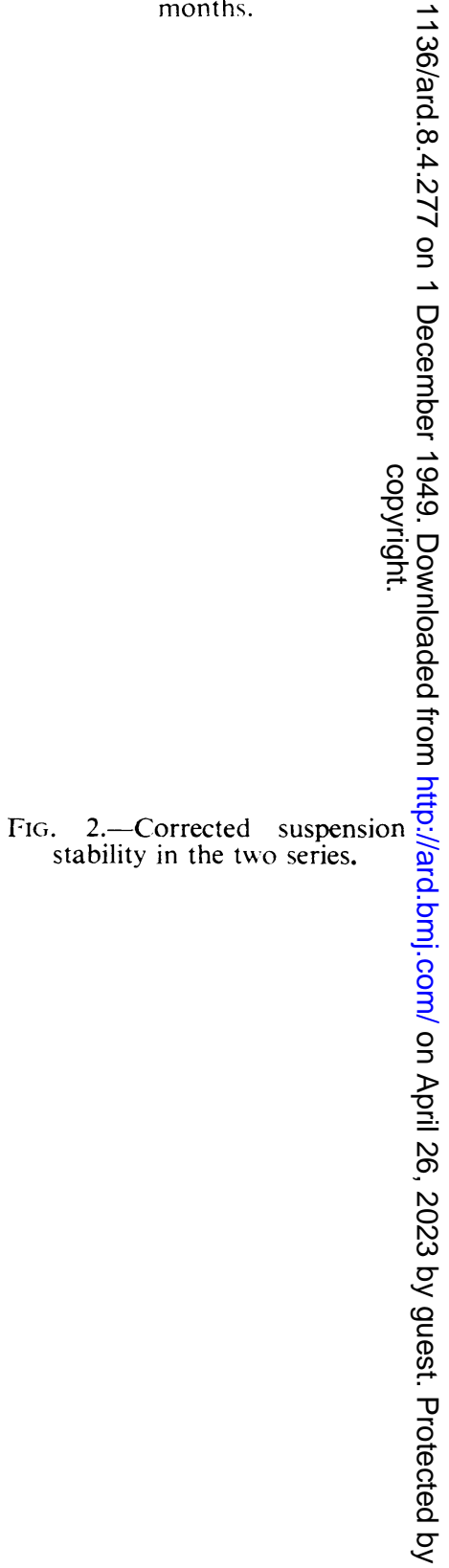


Fig. 3.-Haematocrit in the itwo series.

Fig. 4.-Weight in the two series (ten cases were not recorded in the blood transfusion series, and one case was omitted from the controls).

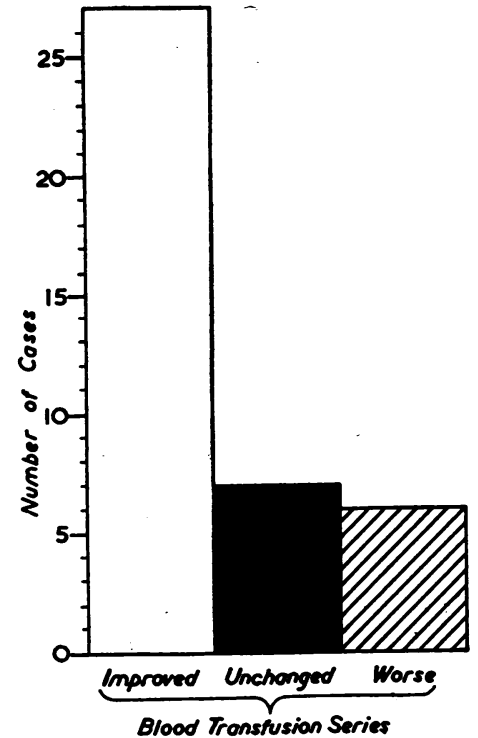

A

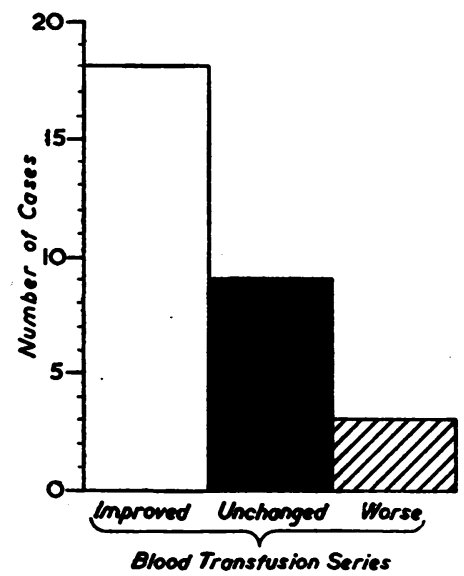

A

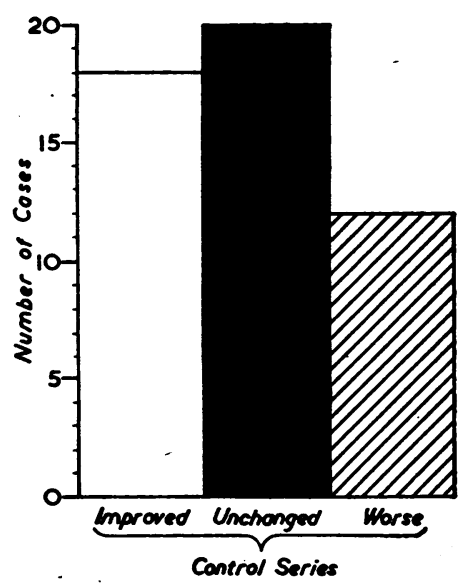

B

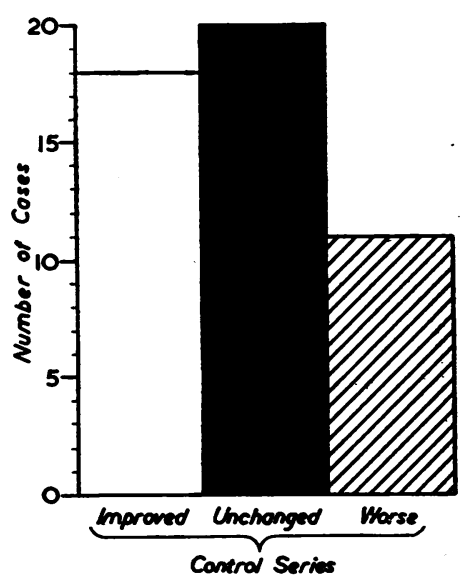

B 


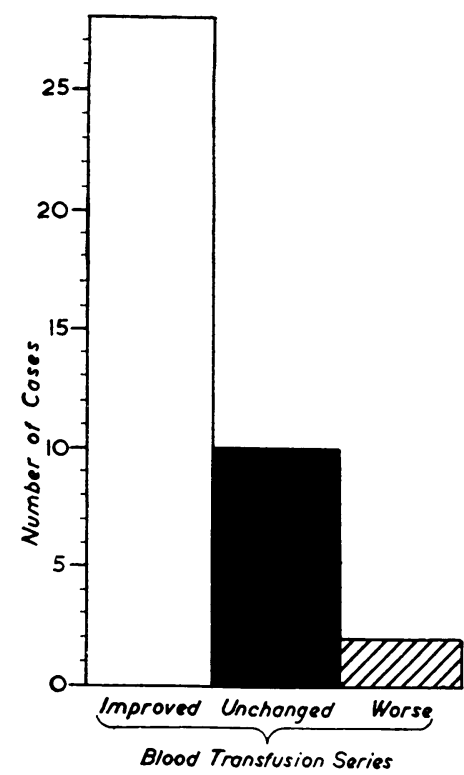

A

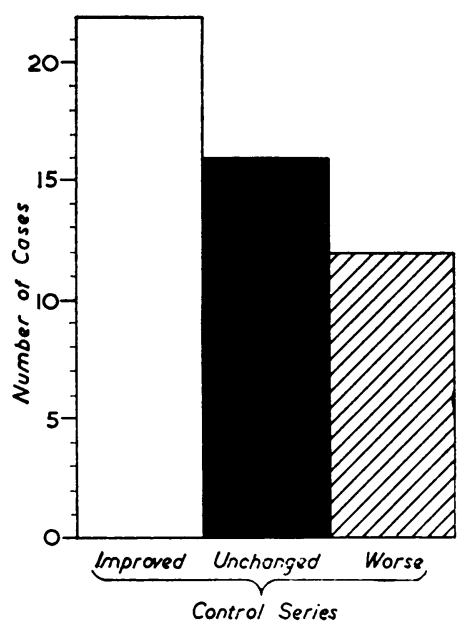

B

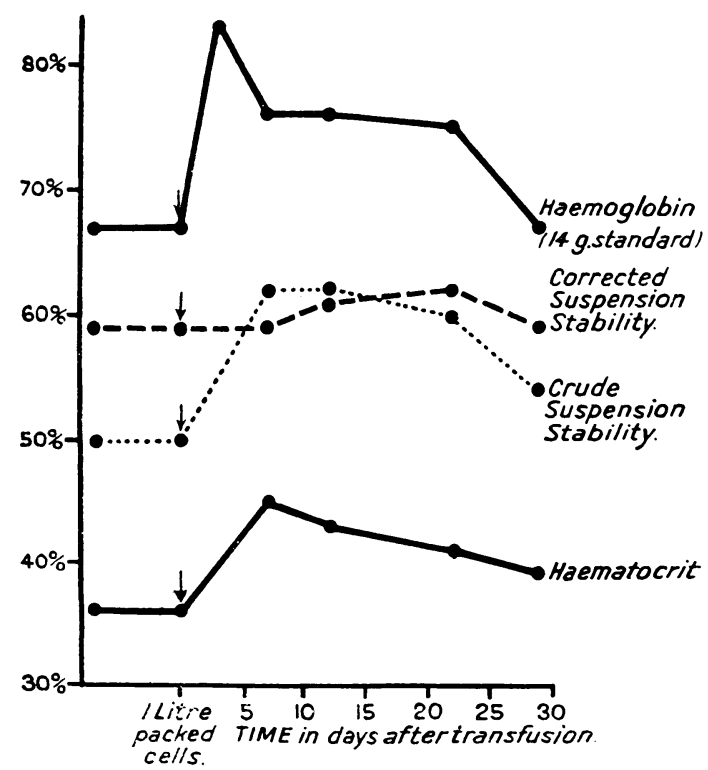

FIG. 6.-Cases with normal plasma protein values before and after transfusion with one litre of packed red cells (twenty-six cases).
FIG. 5.-Clinical assessment the two series. 


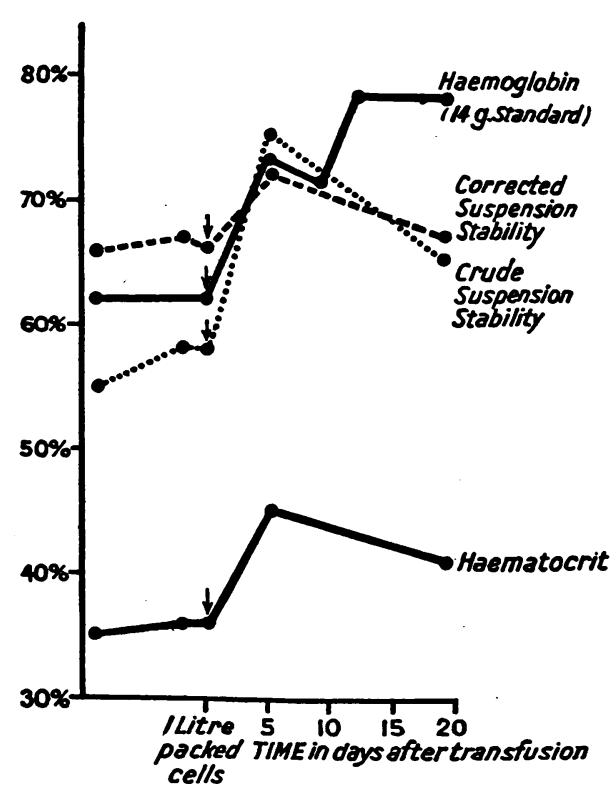

Fig. 8.-Cases with normal plasma protein values becoming abnormal later (nine cases).

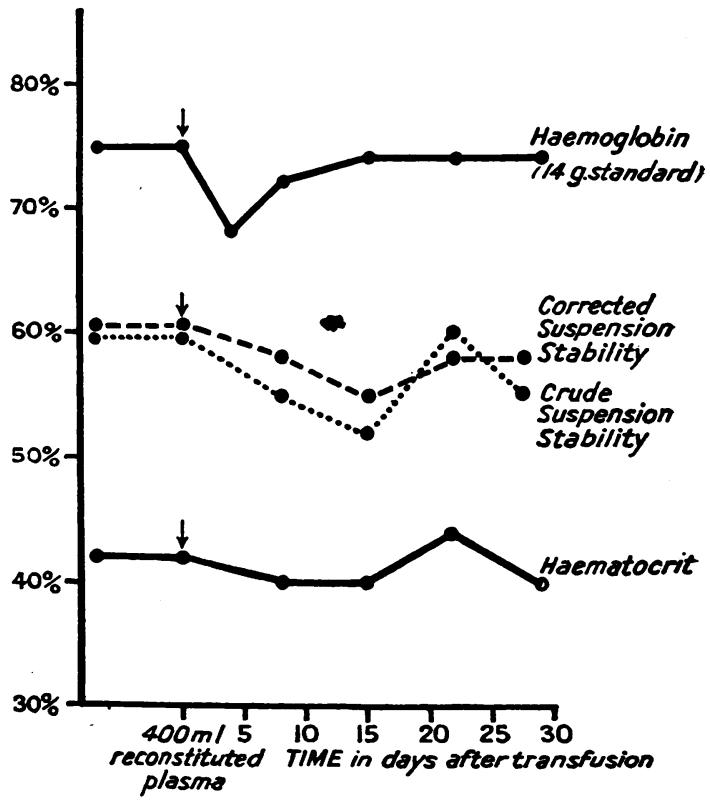

Fig. 9.-Cases treated with plasma transfusion (ten cases).

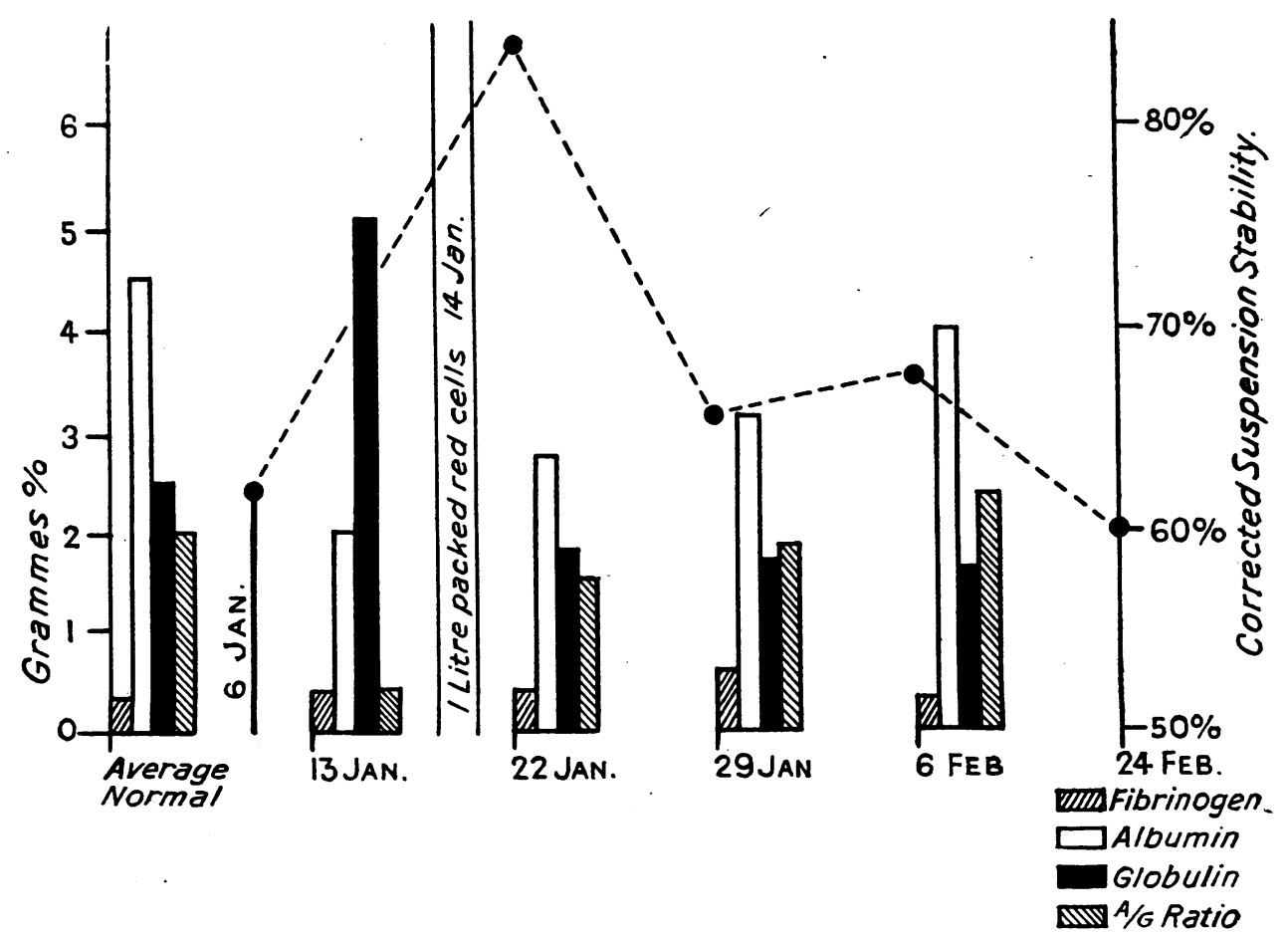

FiG. 10.-Example of abnormal plasma proteins becoming normal after transfusion. 
transfusion of packed cells. All patients who were transfused with blood showed an improvement in the levels of haemoglobin, E.S.R., C.S.S., and haematocrit. This occurred within forty-eight hours after transfusion and had returned to, or nearly to, the previous abnormal value twenty-eight days later. The patients who were transfused with plasma alone showed no improvement in these levels.

Before transfusion, sixteen patients had abnormal plasma proteins with a high globulin, and nine had also a low albumin. Fourteen of these had transfusions of packed cells or whole blood, and two had transfusions of plasma only. Of the fourteen, eleven showed a return to normal protein values during the week after transfusion. At the same time the C.S.S. showed an improvement in all except the three patients in whom the plasma proteins remained abnormal after transfusion. In the two patients with abnormal proteins who were given plasma only, the plasma proteins remained abnormal after transfusion and no improvement in any blood tests was noted. In thirty-four patients where the plasma proteins were at first normal, twenty-six were given transfusions of packed cells or whole blood, and eight were given transfusions of plasma. In only five cases was there any improvement in the C.S.S., and even then this was not so marked as in those eleven cases where a reversal of the abnormal plasma proteins ratio occurred after transfusion.

Where the C.S.S. showed improvement, this was maximal seven to ten days after transfusion and appeared to drop back towards the previous abnormal figure fourteen to twenty-one days afterwards. In nine cases where the plasma proteins were normal before transfusion, abnormal figures occurred afterwards but never within fourteen days of transfusion. The three patients who were given plasma originally and showed no improvement, when subsequently given blood transfusions showed the usual improvement in the blood tests.

In thirty-two cases serum and plasma gel tests were carried out. There seemed to be no correlation between the quantity of the plasma proteins and the reaction to these tests, which appear to be related more to an abnormal state of the plasma colloids than to a quantitative increase of any one protein.

All patients who were given blood transfusions showed clinical improvement, the patients stating that they felt stronger, suffered less pain, and were more fit to undergo the other treatments prescribed. Smooth atrophic skin, cyanosis, coldness, and excessive sweating of the extremities were not infrequently improved after transfusion. No immediate change in the appearance of the arthritis, either clinically or radiologically, was apparent.

\section{Six Months' Follow Up}

So far it has been possible to review fifty patients $\frac{8}{0}$ है who have been readmitted to hospital. Forty of these had had blood transfusion, seven plasma, and three plasma and blood. The results shown? in Tables 1 to 3 have been obtained, an allowance of

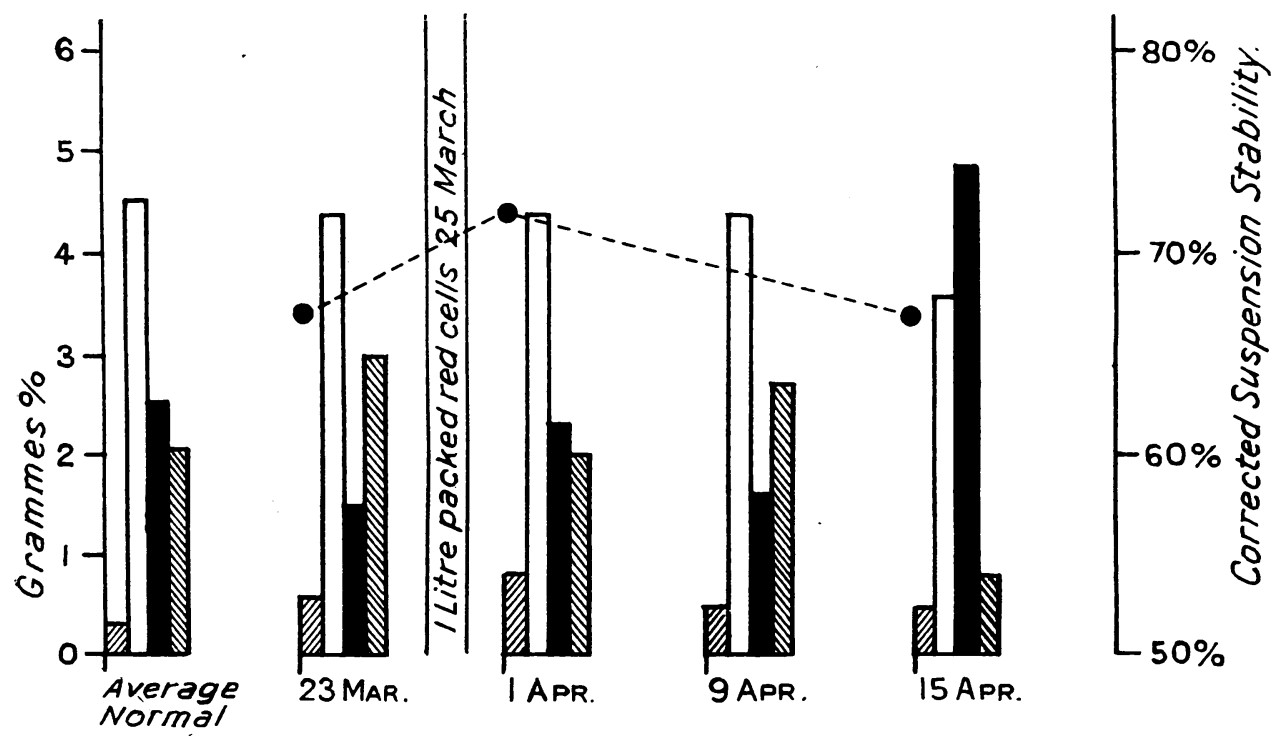

FIG. 11.-Example of normal plasma proteins becoming abnormal after transfusion. 
\pm 2 having been made throughout as the likely margin of error ( $\pm 4 \mathrm{lb}$. in the case of weight).

Twenty-seven cases who were transfused with blood have not returned to hospital, and these have been circulated with a questionnaire : twentytwo report an improvement in their state, three report no change, and two were worse since their last admission with transfusion.

TABLE 1

RESULTS IN FORTY CASES TRANSFUSED WITH PACKED CELLS OR WHOLE BLOOD

\begin{tabular}{l|c|c|c|c|c|c}
\hline & $\begin{array}{c}\text { Crude } \\
\text { E.S.R. }\end{array}$ & C.S.S. & Hb & $\begin{array}{c}\text { Haemato- } \\
\text { crit }\end{array}$ & $\begin{array}{c}\text { Weight* } \\
\text { Clinical } \\
\text { assess- } \\
\text { ment }\end{array}$ \\
\hline Improved . & 26 & 9 & 31 & 27 & 18 & 28 \\
Unchanged & 9 & 12 & 4 & 7 & 9 & 10 \\
Deteriorated & 5 & 19 & 5 & 6 & 3 & 2 \\
\hline
\end{tabular}

* In ten cases the result was not recorded.

\section{Control Series}

This series was compared with fifty patients with a similar type of rheumatoid arthritis who were treated at the Royal National Hospital for Rheumatic Diseases, Bath, during 1948, in exactly similar ways, but who did not have blood or plasma transfusions. The results in the control series are shown in Table 4

\section{Conclusions}

From the follow-up, the following facts emerge. The crude sedimentation rate appears to be better in the series given blood transfusion than in the control series, and there appears to be no significant difference in the values of the corrected sedimentation rate or weight between those who had been given blood transfusions and those who had not.

The haematocrit levels were better in those who had been given a transfusion, and the clinical assessment was better in those who had been given

TABLE 2

RESULTS IN SEVEN CASES TRANSFUSED WITH PLASMA

\begin{tabular}{l|c|c|c|c|c|c}
\hline & $\begin{array}{c}\text { Crude } \\
\text { E.S.R. }\end{array}$ & C.S.S. & Hb & $\begin{array}{c}\text { Haemato- } \\
\text { crit }\end{array}$ & Weight* & $\begin{array}{c}\text { Clinical } \\
\text { assess- } \\
\text { ment }\end{array}$ \\
\hline $\begin{array}{l}\text { Improved . } \\
\text { Unchanged }\end{array}$ & 2 & 2 & 1 & 4 & 2 & 3 \\
Deteriorated & 3 & 5 & 2 & 1 & 4 & 4 \\
\hline
\end{tabular}

* One case was not recorded.

a transfusion. This is in agreement with our general impressions during the past year.

The results of the plasma protein estimations are difficult to assess, and a larger number will have to be done before any definite conclusions can be
TABLE 3

RESULTS IN THREE CASES TRANS USED WITH PLASMA AND BLOOD

\begin{tabular}{l|c|c|c|c|c|c}
\hline & $\begin{array}{c}\text { Crude } \\
\text { E.S.R. }\end{array}$ & C.S.S. & Hb & $\begin{array}{c}\text { Haemato- } \\
\text { crit }\end{array}$ & Weight* & $\begin{array}{c}\text { Clinical } \\
\text { assess- } \\
\text { ment }\end{array}$ \\
\hline $\begin{array}{l}\text { Improved . } \\
\text { Unchanged }\end{array}$ & 2 & 1 & 3 & 1 & - & 1 \\
Deteriorated & - & 1 & - & 2 & - & 1 \\
\hline
\end{tabular}

* One case was not recorded.

reached. We have confirmed that in a certain number of cases the plasma proteins are disturbed, and in certain of these cases blood transfusion appears to return these values to normal.

Plasma transfusions in the cases we have treated appear to have no effect either on the blood chemistry or on the disease process.

The arthritic condition appears to be little affected by blood transfusion, and it is on the general state of health that the greatest effect is noticed. We therefore believe that this form of therapy is not specific, but is a useful supporting measure and merits much greater use.

Our indications for transfusion are as follows : (1) a haematocrit below 35 per cent., or alternatively a haemoglobin reading below 60 per cent.; (2) an active condition which does not react to other forms of treatment ; (3) where it is considered that a patient is not fit, on account of his general condition,

TABLE 4

RESULTS IN THE CONTROL SERIES

\begin{tabular}{l|c|c|c|c|c|c}
\hline & $\begin{array}{c}\text { Crude } \\
\text { E.S.R. }\end{array}$ & C.S.S. & Hb & $\begin{array}{c}\text { Haemato- } \\
\text { crit }\end{array}$ & Weight* & $\begin{array}{c}\text { Clinical } \\
\text { assess- } \\
\text { ment }\end{array}$ \\
\hline Improved . & 22 & 26 & 3 & 18 & 18 & 22 \\
Unchanged & 14 & 4 & 1 & 20 & 20 & 16 \\
Deteriorated & 14 & 20 & 5 & 12 & 11 & 12 \\
\hline
\end{tabular}

* In one case the result was not recorded.

for other treatments considered necessary, such as aurotherapy, balneotherapy, manipulation under general anaesthesia, or other operative interference.

\section{Summary}

The effect of transfusions of blood and plasma on patients suffering from rheumatoid arthritis is described.

The haematological tests done in each case are enumerated, together with results in twenty-five normal controls.

In sixty cases in which the plasma proteins were estimated initially, fibrinogen values were high in thirty-eight, high normal in sixteen, and within normal limits in only six cases; globulin values 
were high in twenty-one cases, ten of these showing a concomitant low albumin figure.

All patients showed secondary microcytic anaemia of varying severity, and abnormal crude and corrected erythrocyte sedimentation rates.

Fifty patients have been treated by transfusion and adequately followed up. Forty have been given blood transfusions, and ten plasma, three of the latter later having blood in addition.

All patients given blood showed an immediate improvement in levels of haemoglobin, haematocrit, and erythrocyte sedimentation rate. This occurred within forty-eight hours of transfusion, and had returned to, or nearly to, the previous abnormal value twenty-eight days later. Cases given plasma alone showed no improvement in these estimations.

Of fourteen patients with abnormal albumin and globulin figures initially who were given blood, eleven showed normal values during the week after transfusion. In two similar patients given plasma only, no such change was observed.

Serum and plasma gel tests showed no correlation between protein abnormalities and test reactions.

Fifty patients have been reviewed six months later on readmission to hospital and compared with fifty similar patients who had been treated in exactly similar fashion with the exception of blood transfusion. There was no significant difference in the values of corrected suspension stability or weight in the two series, although the crude erythrocyte sedimentation rate was better for the blood transfusion series. The haematocrit levels and clinical assessment showed a much better figure for those given blood transfusions.

The indications for blood transfusion in rheumatoid arthritis are described. It is considered that it is on the general condition of the patient that the greatest effect is noticed, and the arthritis is not much affected by transfusion. It is suggested that it is a useful supporting measure and merits greater use in this disease.

We should like to thank Dr. H. J. Gibson for his help in this investigation, Mr. E. W. Richardson, and Mr. D. S. Bidmead for assisting in the pathological investigations. We are also grateful to the Editor of the Proceedings of the Royal Society of Medicine for permission to publish figures.

\section{REFERENCES}

Appelqvist, O., and Holsti, O. (1947). Schweiz. med. Wschr., 77, 977.

Collins, D. H., Gibson, H. J., Race, J., and Salt, H. B. (1939). Annals of the Rheumatic Diseases, 1, 333.

Copeman, W. S. C. (1931a). Brit. med. J., 2, 1130. (1931b). Proc. R. Soc. Med., 24, 1509.

Hartung, E. F. (1943). Bull. N.Y. Acad. Med., 19, 693. Hench, P. S. (1938). Proc. Mayo Clin., 13, 161.
Holbrook, W. P., and Hill, D. F. (1936). J. Amer. med. Ass., 107, 34.

Simpson, N. R. W., and Hall Brooks, D. (1948). Proc. $R$. Soc. Med., 41, 609.

Effet de la Transfusion du Sang sur l'Arthrite Rhumatismale

\section{RÉSUMÉ}

On décrit l'effet de la transfusion du sang et du plasma sur des malades atteints d'arthrite rhumatismale. On énumère les épreuves hématologiques dans tous les cas, ainsi que les résultats chez 25 témoins normaux.

Sur 60 malades chez qui les proteïnes du plasma furent préalablement déterminées, les chiffres du fibrinogène étaient élevés chez 38 , près de la limite supérieure normale chez 16 et endéans les limites normales chez 6 seulement ; les chiffres de la globuline étaient élevés chez 21 , dont 10 présentaient une diminution concomitante de l'albumine.

Tous les malades présentaient une anémie microcytique secondaire de sévérité variable et leur sédimentation globulaire, brute et corrigée, était anormale.

Cinquante malades furent traités par la transfusion du sang et étudiés d'une façon appropriée. Quarante d'eux reçurent du sang total et dix.du plasma ; trois de ces derniers reçurent plus tard du sang en plus.

Chez tous les malades transfusés il y eut une amélioration immédiate portant sur le niveau de l'hémoglobine, le volume corpusculaire et sur la sédimentation globulaire. Ceci eut lieu quarante huit heures après la transfusion ; vingt huit jours plus tard on constata un retour aux chiffres antérieurs, ou à peu près. Chez ceux qui reçurent rien que du plasma on ne vit aucune amélioration de la formule sanguine.

Chez onze malades sur quatorze, chez qui les chiffres d'albumine et de globuline avaient été anormaux, ces chiffres devinrent normaux au cours de la semaine qui suivit la transfusion. On n'observa aucune modification chez deux malades similaires qui reçurent du plasma seulement.

On ne trouva aucun rapport entre les anomalies de la formule sanguine et les résultats des épreuves colloidales pour le sérum et le plasma.

Cinquante malades furent re-examinés 6 mois plus tard lors de leur retour à l'hôpital et is furent comparés aux cinquante malades similaires traités d'une façon exactement similaire, à l'exception de la transfusion sanguine. On ne trouva aucune différence significative entre ces deux groupes en ce qui concerne les chiffres corrigés de la stabilité de la suspension ou le poids ; toutefois la sédimentation globulaire brute fut meilleure chez les transfusés. De même, la détermination du volume corpusculaire et l'examen clinique donnèrent un résultat meilleur chez les transfusés.

On décrit les indications de la transfusion du sang dans l'arthrite rhumatismale. On considère que le meilleur effet est produit sur l'état général du malade et que l'arthrite est à peine influencée par la transfusion. On suggère que c'est une mesure adjuvante utile et qu'elle mérite une application plus fréquente dans cette maladie. 